\title{
THE RELATION BETWEEN BODY SIZE AND NUMBER OF EGGS IN THE FRESHWATER PRAWN, MACROBRACHIUM LAMARREI (H. MILNE EDWARDS) (DECAPODA, CARIDEA)
}

\author{
BY \\ KATRE SHAKUNTALA \\ Department of Zoology, Bangalore University, Bangalore 560001, South India
}

\section{INTRODUCTION}

To ensure a greater number of surviving juveniles, a species may produce large numbers of eggs as in the cod, Gadus morrbua L., or fewer, larger sized eggs, as in the freshwater fishes (Blaxter, 1969) and some crustaceans (Allee \& Schmidt, 1957), from which more viable individuals may be hatched. Among oviparous forms, the success of crustaceans can be attributed to the fact that most of them carry their developing eggs until hatching; this 'parental care' results in a greater survival of the eggs. Among many factors that regulate the number of eggs carried by a female, the size of the mother animal appears to be an important one (e.g. in fishes, Blaxter, 1969). In several marine crustaceans, the number of eggs carried has been found to be linear to the length of the female (e.g. Palaemon elegans Rathke (as Leander squilla) and Palcemon serratus (Pennant), cf. Forster, 1951; several marine Malacostraca, Jensen, 1958; Sphaeroma bookeri Leach and Gammarus zaddachi Sexton, cf. Kinne, 1954, 1961; Crangon septemspinosa Say, cf. Price, 1962; Pandalopsis dispar, Collin et al., 1972; and Panulirus longipes, Morgan, 1972). Jensen (1958) working on several marine Malacostraca concluded that the "absolute number" of eggs (the total number of eggs carried in all the broods of an individual) was determined by environmental factors; however, the "relative number" of eggs (total number of eggs carried in a single brood at any one time) exhibits a linear relationship to the volume of the mother and hence is dependent upon the mother itself. It is not clear whether the relationship between the egg number and mother's volume as observed by Jensen for marine malacostracans would also hold true for freshwater crustaceans. As most decapods carry the eggs attached to the plumose hairs of their abdominal appendages, it remains to be seen whether the restricted space thus available for the attachment of these eggs on the appendages, imposes certain restrictions on the egg size and/or number of eggs carried by the female in a single brood. The present paper reports the observations on the egg size/number in relation to the mother animal in the freshwater prawn Macrobrachium lamarrei (H. Milne Edwards, 1837). 

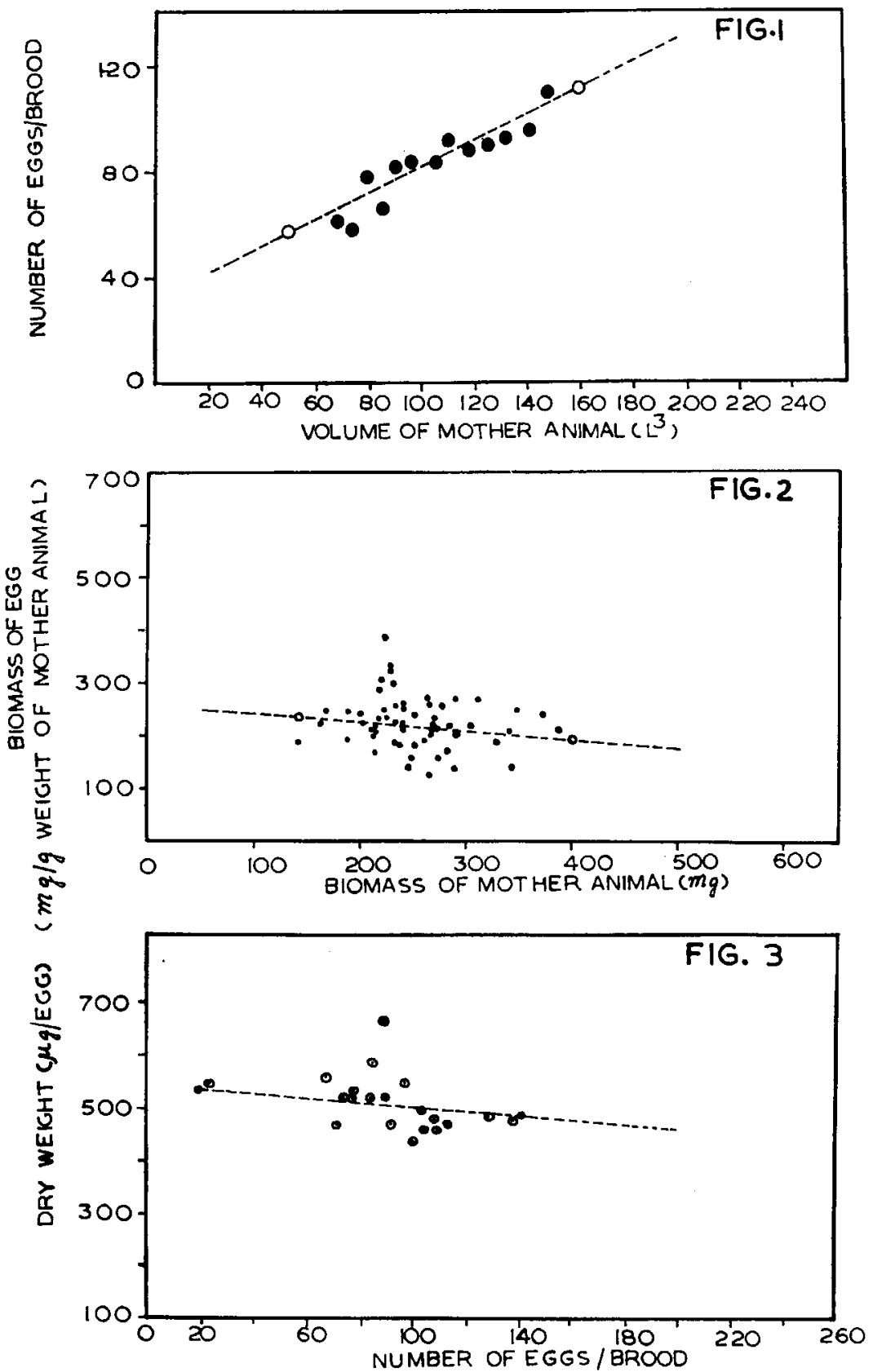

Figs. 1-3. Macrobrachium lamarrei (H. Milne Edwards). 1, regression showing the direct linear relationship between total egg number per brood and the volume (length ${ }^{3}$ ) of the mother animal $\mathrm{Y}=85.48+0.4858(\mathrm{X}-105.79)$.

2 , regression showing the inverse linear relationship between the total biomass of eggs per brood (expressed in $\mathrm{mg} / \mathrm{g}$ dry weight of mother animal) and the biomass of the female $\mathrm{Y}=220.54-$ $0.158(\mathrm{X}-251.60)$.

3 , regression showing the inverse linear relationship between the individual egg weight as function of the total number of eggs per brood of mother animal $(4.6 \mathrm{~cm}$ body length) $\mathrm{Y}=0.51-0.000454$ $(\mathrm{X}-91.35)$. 


\section{MATERIALS AND METHODS}

Macrobrachium lamarrei, a freshwater prawn, is widely distributed in India (Kemp, 1915). It has also been recorded in the estuaries, where the salinity ranged from traces to $15.9 \%$ (Rajyalakshmi, 1961). For the present study, gravid prawns were collected from the Bellandur fish farm, near Bangalore, South India. The prawns caught in several collections throughout the years 1969 to 1972 were transferred into individual glass battery jars (capacity: $500 \mathrm{ml}$ ) containing filtered, aerated $(4.0 \mathrm{ml} \mathrm{O} / 1)$ freshwater, with an ambient temperature of $25^{\circ} \pm 2^{\circ} \mathrm{C}$. These prawns were fed chopped pieces of the fish Gambusia affinis.

The total length of the mother animals was measured from the tip of the rostrum to the end of the telson; their biomass was measured after drying them to weight constancy overnight at $95^{\circ} \mathrm{C}$ in a hot air oven.

The egg mass was slowly released from the plumose hairs of the pleopods onto a glass slide, the connections between the eggs removed and the number of eggs per brood of the mother was counted. The dry weight of eggs was determined after drying them to weight constancy at $95^{\circ} \mathrm{C}$.

\section{RESULTS}

Egg number/weight and its relation to mother animals. - A little harsh handling, jolting during transportation and storage of Macrobrachium lamarrei led to the loss of eggs and the number of eggs counted from such females could be rather erroneous. Hence care was taken to minimise handling of the animals, avoid jolting during transportation and all the countings of egg number were made on the very day of the collection. There is considerable variation in the egg number, even among the individuals of the same size group collected on the same day (Table I). Following the formula of regression analysis (Draper \& Smith, 1966) an equation $\mathrm{Y}=85.48+0.4858(\mathrm{X}-1$ 105.79) was derived. Table II presents the analysis of variance, wherein statistically both the linearity of the line and the slope are proved to be significant. Figure 1 gives the regression line arrived at, for the number of eggs versus volume of the mother prawns, which shows that the egg number is linear to the volume (length ${ }^{3}$ ) of the mother animal. It shows that for every increase in ten units $\left(\mathrm{L}^{3}\right)$ in the volume of the prawn (taking length in $\mathrm{cm}$ ) the egg number increases by 4.86, i.e., if the mother's volume is 90 , the number of eggs carried by her would be about 76.8 and if it is 100 , then the number of eggs carried by her would be 81.67 . The present work brings supporting evidence from a freshwater prawn to the conclusions arrived at by Jensen (1958).

Biomass of eggs versus biomass of mother. - To find out the relationships between the total biomass of eggs carried by a mother Macrobracbium lamarrei to the biomass of the mother itself, regression analysis was applied. Generally it was expected that this would also bear a direct and proportional relationship, as 


\section{TABLE I}

Macrobracbium lamarrei (H. Milne Edwards), egg counts from mothers of different body lengths (1) or volumes $\left(1^{3}\right)$

1

(cm) $\quad X=1^{3} \quad Y=$ Number of eggs per female

$\begin{array}{lllllll}4.1 & 68.921 & 61 & 29 & 57 & 77 & 78\end{array}$

$\begin{array}{llllllll}4.2 & 74.083 & 68 & 70 & 22 & 77 & 71 & 47\end{array}$

$\begin{array}{llllllll}4.3 & 79.507 & 31 & 75 & 82 & 89 & 100 & 90\end{array}$

$\begin{array}{llllllll}4.4 & 85.184 & 54 & 23 & 73 & 25 & 56 & 58\end{array}$

$\begin{array}{llllllll}4.5 & 91.125 & 101 & 95 & 66 & 82 & 67 & 142\end{array}$

$\begin{array}{llllllll}4.6 & 97.336 & 68 & 46 & 20 & 94 & 108 & 113\end{array}$

$\begin{array}{llllllll}4.7 & 103.823 & 49 & 103 & 92 & 117 & 75 & 6\end{array}$

4.8

4.9

5.0

5.1

5.2

5.3

110.592

117.649

125.000

132.651

140.608

$148.877 \quad 88$

$83 \quad 100 \quad 96$

$\begin{array}{lll}99 & 89 & 72\end{array}$

$\begin{array}{lll}39 & 97 & 4\end{array}$

$\begin{array}{lll}97 & 108 & 110\end{array}$

$\begin{array}{lll}19 & 129 & 98\end{array}$

$\begin{array}{lll}88 & 129 & 158\end{array}$

$94 \quad 66 \quad 90$

$\begin{array}{rrr}94 & 66 & 90 \\ 101 & 80 & 86\end{array}$

$85 \quad 10$

103

$\begin{array}{llll}97 & 74 & 78 & 81\end{array}$

$\begin{array}{llll}40 & 122 & 59 & 101\end{array}$

$76 \quad 11$

\section{TABLE II}

Macrobracbium lamarrei ( $\mathrm{H}$. Milne Edwards), table of analysis of variance. Egg counts from mothers of different body lengths (1) or volumes $\left(1^{3}\right)$

$\begin{array}{lcc}\text { Total } & \begin{array}{c}\text { Degrees of } \\ \text { freedom }\end{array} & \text { Sum of squares } \\ \text { Regression } & 114 & 89217 \\ \text { Residual } & 1 & 15855 \\ \text { Lack of fit } & 113 & 73362 \\ \text { Error } & 11 & 3854 \\ \text { r } & 102 & 69508\end{array}$

$\begin{array}{cc}\begin{array}{c}\text { Mean of } \\ \text { squares }\end{array} & \text { P ratio } \\ - & - \\ 15855.00 & - \\ 649.22 & 24.42 \\ 350.36 & - \\ 681.45 & 0.5141\end{array}$

observed in the fish Tilapia (Peter, 1963). Surprisingly, the results showed an inverse relationship, yielding an equation, $\mathrm{Y}=220.54-0.158(\mathrm{X}-251.60)$. Figure 2 represents the regression line arrived at for this relationship between the biomass of the eggs and biomass of the mother. This shows that for every $100 \mathrm{mg}$ increase in the total dry weight of the mother, there would be a decrease of $15.81 \mathrm{mg}$ in terms of eggs expressed as $\mathrm{mg} / \mathrm{g}$ weight of the mother. It may therefore be inferred that egg size of larger females is smaller than those carried by smaller females. The large females carried less biomass of eggs per unit biomass owing to the decreased size of the individual eggs rather than to the decreased egg number.

Dry weight/egg versus total number of eggs carried by the mother. - The average values of individual egg weights are plotted as function of the total number of eggs carried by females of more or less similar size (fig. 3 ) and the regression obtained for individuals belonging to $4.6 \mathrm{~cm}$ size is $\mathrm{Y}=0.51-0.000454$ $(X-91.35)$, i.e. for every increase of 10 eggs carried by the female there is a 
decrease in the individual dry weight of I stage eggs (eggs collected soon after spawning) by $0.005 \mathrm{mg}$. Similarly, the decrease in the egg size for an increase in every 10 eggs, say from 60 to 70 , was found to be $0.01 \mathrm{mg}$ for females belonging to $5.0 \mathrm{~cm}$ length. Such a relationship suggested for fishes (Blaxter, 1969) has been recorded in the fish Apogon imberbis and A. conspersus by Garnaud (quoted by Smith, 1957).

\section{DISCUSSION}

While there are many reports relating the mother's size to fecundity in terms of number of eggs in both marine (authors quoted above) and freshwater crustaceans (Raman, 1965; Rajyalakshmi, 1961), data relating the total biomass of eggs to the body weight of the female are wanting. In Macrobracbium lamarrei it is clear that the total biomass of eggs/brood is inversely proportional to the unit body weight of the female. One reason that can be adduced for this indirect relationship is that the individual egg size decreased with increasing body weight. To check up this the following calculations were made under the assumption that the egg weight $(0.49 \mathrm{mg} / \mathrm{egg})$ remained constant in individuals of different body size. For instance, individuals of the size $4.0,4.5$ and $5.0 \mathrm{~cm}$ body length carried 64, 84 and 105 eggs respectively (Table III). The total biomass of the eggs in a brood then could have been $31.36,41.16,51.45 \mathrm{mg}$ and would yield 221.9, 206.2 and $177.9 \mathrm{mg} / \mathrm{g}$ female. Therefore, there is a decrease in biomass of eggs per se upto $4.5 \mathrm{~cm}$ length of the female. Beyond this size in addition to the decrease in egg weight other yet unknown factor(s) seems to be involved; senility may be one such factor.

Among the individuals of Macrobracbium lamarrei belonging to a particular size, the size of the individual egg has been shown to be dependent upon the total number of eggs present in the brood. In many crustacean species, the eye stalk,

\section{TABLE III}

Macrobracbium lamarrei ( $\mathrm{H}$. Milne Edwards), calculation procedure to estimate the biomass of eggs produced by females of different body size when the individual egg weight was taken to be constant

Parameters

Mothers length $(\mathrm{cm})$

Dry body weight (mg)

Number of eggs/brood

Dry weight/egg (mg)

Observed total biomass of eggs in the brood ( $\mathrm{mg}$ )

Observed biomass of eggs $/ \mathrm{g}$ dry weight of female ( $\mathrm{mg}$ )

Calculated total biomass of eggs in the brood ( $\mathrm{mg}$ )

Calculated biomass of $\mathrm{egg} / \mathrm{g}$ dry weight of female (mg)

$\begin{array}{ccc} & \text { Values } & \\ 4.0 & 4.5 & 5.0 \\ 141.4 & 199.6 & 289.6 \\ 64 & 84 & 105 \\ 0.49 & 0.47 & 0.43 \\ 31.36 & 36.68 & 45.15 \\ 221.9 & 183.7 & 155.5 \\ 31.36 & 41.16 & 51.45 \\ 221.9 & 206.2 & 177.9\end{array}$


ganglionic X organs, or sinus glands are known to contain an "ovarian-inhibiting" neurohormone which prevents vitellogenesis. The production of this factor is known to be apparently regulated by environmental stimuli that impinge on sensory receptors (Turner, 1966: 77). Vitellogenesis commences when the level of this neurohormone is reduced or is absent. The size of each egg then depends on the duration of vitellogenesis during which the yolk is deposited, as well as the total number of eggs competing to share this yolk deposition.

\section{ACKNOWLEDGEMENTS}

The author wishes to express her deep gratitude to Dr. T. J. Pandian, formerly lecturer in Zoology, Bangalore University, Bangalore for supervising the present research work and offering helpful suggestions. The research assistantship offered by the Bangalore University is gratefully acknowledged.

\section{ZUSAMMENFASSUNG}

Je nach der Körpergröße trug eine weibliche Macrobrachium lamarrei 30 bis 160 Eier. Die Gesamtzahl der Eier pro Brut ist eine lineare Funktion des Gesamtvolumens des weiblichen Tieres. Als Funktion der Masseneinheit des weiblichen Tieres ausgedruckt, ist die Gesamtbiomasse der Eier pro Brut der Gesamtbiomasse des Muttertieres umgekehrt proportional. Unter Tieren gleicher Körpergröße, ist die Größe eines Eies von der Gesamtzahl der Eier in der betreffenden Brutabhängig. Je größer die Zahl der Eier in der Brut, desto kleiner ist die Größe jedes Eies.

\section{LITERATURE CITED}

Allee, W. C. \& K. P. Schmidt, 1957. Ecological animal geography. (New York).

Blaxter, J. H. S., 1969. Development of eggs and larvae. In: W. S. HoAR \& D. J. RandAll, (eds.), Fish physiology, 3. (Academic Press, New York).

Colin, H. K., K. CHEw \& V. PRice, 1972. Relation of the egg number to carapace length of sidestripe shrimp Pandalopsis dispar, from Dabob Bay, Washington. Journ. Fish. Res. Bd. Canada., 29: $464-465$.

Draper, N. \& H. SMrTh, 1966. Applied regression analysis. (John Wiley \& Sons, New York).

Forster, G. R., 1951. The biology of the common prawn Leander serratus Pennant. Journ. mar. biol. Ass. U. K., 30 (2): 333-360.

JENSEN, J. P., 1958. The relation between body size and number of eggs in marine malacostrakes. Meddel. Danmarks Fisk-og Havundersøg., (n. ser.) 2: 1-25.

Kемр, S., 1915. Fauna of the Chilka Lake. Crustacea-Decapoda. Mem. Indian Mus., 5: 199-325.

KINNE, O., 1954. Eidonomie, Anatomie und Lebenszyklus von Sphaeroma hookeri Leach. Kieler Meersforsch., 10: 100-120.

- 1961. Growth, molting frequency, heartbeat, number of eggs and incubation time in Gammarus zaddachi exposed to different environments. Crustaceana, 2 (1): 26-36.

Morgan, G. R., 1972. Fecundity in the western rock lobster Panulirus longipes cygnus (George) Crustacea-Decapoda. Australian Journ. Mar. Freshwater Res., 23 (2): 133-141.

Peter, H. M., 1963. Egg number, egg weight and development of the spawn in the genus Tilapia. Internat. Rev. ges. Hydrobiol, 48 (4): 547-576.

Price, K. S., 1962. Biology of the sand shrimp Crangon septemspinosa in the shore zone of the Delaware Bay region. Chesapeake Sci., 3: 244-255.

RajYalakshmI, T., 1961. Studies on maturation and breeding in some estuarine palaemonid prawns. Proc. National Inst. Sci. India, 27 (B) (4).

RAMAN, K., 1965. Observations on the fishery and biology of the giant freshwater prawn, Macrobrachium rosenbergii (De Man). Proc. Symp. Crustacea, Mar. Biol. Ass. India, 2: 649-669.

Smrth, S., 1957. Early development and hatching. In: M. E. Brown (ed.), The physiology of fishes, 1. (Academic Press, New York).

Turner, C. D., 1966. General endocrinology. (W. B. Saunders, Philadelphia).

Received for publication 16 October 1974. 